\title{
PELATIHAN PENJUALAN ONLINE UNTUK IBU-IBU PKK DI SAUNG SINGGAH TPU PONDOK KOPI, JAKARTA TIMUR
}

\author{
Melani Quintania ${ }^{1}$, Resa Nurlaela Anwar ${ }^{2}$, Ellena Nurfazria Handayani ${ }^{3}$ Firsan Nova $^{4}$ \\ $1,2,3,4$ Universitas Darma Persada \\ Email: melani_quintania@fe.unsada.ac.id
}

\begin{abstract}
The purpose of this study is to provide training in the form of skills in building onlinebased businesses. In simple terms, the activity trains participants on how to market a product using the internet as the main capital. This online business training consists of three parts, namely providing material about business online, the direct practice of creating an account and using social media Instagram and marketplaces, and creating persuasive messages in order to attract buying interest. The results of this study are quite good. Housewives at Saung Singgah TPU Pondok Kopi, who participated in this training, we're able to understand the online business well, were able to create accounts on social media Instagram and the marketplace as a means of online sales quite well even though there were still mothers in making persuasive messages. -Mothers who have not been able to and have not been able to make good persuasive messages. It is hoped that the sustainability of this activity will provide deeper knowledge and insights about onlinebased businesses through social media and marketplaces.
\end{abstract}

Keywords: Community empowerment, Online Business, Social Media and Marketplace

\section{PENDAHULUAN}

Perkembangan teknologi informasi sangat pesat. Salah satu contohnya adalah perkembangan telepon seluler dan internet, keberadaannya memberikan pengaruh bagi berbagai aspek kehidupan. Baik kehidupan secara individu, sosial maupun yang terkait dengan dunia usaha atau bisnis. Selain mempermudah dan mempercepat proses komunikasi dan informasi, teknologi informasi juga dimanfaatkan dalam kegiatan usaha atau bisnis. Banyak alat komunikasi dan informasi yang digunakan dalam kegiatan dunia usaha, seperti penggunaan telepon, fax, sms, email, website dan lain-lain.

Internet bukan hal asing lagi bagi masyarakat. Hampir setiap hari mereka mengakses internet. Entah itu untuk sekadar berkomunikasi atau melihat live streaming maunpun aktivitas lainnya. Dalam kaitannya dengan dunia kerja, internet menjadi salah satu wadah untuk meningkatkan persaingan bisnis mereka. Ketatnya persaingan dalam bisnis mereka rela melakukan berbagai cara dengan tujuan untuk mendapatkan hati para pembeli dengan memasarkan berbagai produk-produk yang terbaru (Hidayah, Utami, Yunita, Tarwoto, \& Yulistia, 2019). 
Indonesia tercatat sebagai pengguna internet terbesar keenam di dunia (Ramadhan, 2018). Menurut survei yang telah dilakukan oleh Asosiasi Penyelenggara Jasa Internet Indonesia (APJII) pengguna internet di Indonesia sudah mencapai 143,26 juta. Angka ini meningkat sebesar 10,56 ribu pengguna dari sebelumnya 132,7 juta pengguna pada tahun 2016. Peningkatan tersebut dipicu oleh peningkatan jumlah penduduk Indonesia. Tahun 2016 total penduduk Indonesia mencapai 256,2 juta orang dan mengalami peningkatan pada tahun 2018 sebesar 5,8 jutan (Nainggolan, 2018). Posisi tersebut menunjukkan bahwa masyarakat Indonesia telah banyak yang menggunakan internet.

Pelatihan penjualan online merupakan pilihan yang tepat untuk mengatasi masalah tersebut. Dalam pelatihan ini nantinya masyarakat akan diajari bagaimana cara menjual produk mereka di berbagai media (seperti web atau media sosial). Kemudian akan dikenalkan juga bagaimana memilih situs yang tepat untuk mengembangkan ataupun membangun usaha bisnis mereka.

Berdasarkan analisis situasi di atas, kami tertarik untuk melakukan pengabdian kepada masyarakat khususnya untuk ibu- ibu PKK di Rumah Singgah Taman Pemakaman Umum Pondok Kopi Jakarta Timur untuk membantu masyarakat untuk memahami dan mampu menerapkan ilmu yang didapatkan dari pelatihan penjualan online tersebut. Program ini sebagai kelanjutan dari program pelatihan pembuatan aksesoris perca sebagai dasar pembekalan keterampilan dan pelatihan menjual online sebagai bagian dari pelatihan memasarkan produk yang telah mereka buat.

\subsection{Rumusan Masalah}

Pengetahuan tentang digital marketing tidak hanya pada kajian promosi dan pemasaran saja, tetapi juga sudah mencakup pada penggunaan new media internet dalam proses komunikasi dan penjualan. Sementara itu banyak masyarakat yang menggunakan media internet ini namun belum mengerti bagaimana menggunakan teknologi secara bijak. Ibu-ibu PKK di Saung Singgah telah mendapatkan pengetahuan dan keterampilan membuat aksesoris wanita yang bernilai jual ekonomis dari kain perca pada kegiatan pengabdian sebelumnya, namun di lapangan mereka kesulitan dalam menjual produknya kepada pasar sasarannya. 
Rumusah masalah dalam kegiatan pengabdian pada masyarakat ini adalah sebagai berikut :

a. Bagaimanakah proses pengenalan konsep dasarn menjual melalui media internet (internet marketing) kepada ibu-ibu PKK di Saung Singgah TPU Pondok Kopi Jakarta Timur?

b. Bagaimanakah proses pengenalan metode penjualan melalui internet melalui media sosial?

c. Bagaimanakah proses pengenalan metode penjualan melalui internet melalui marketplace?

\subsection{Tujuan Kegiatan}

Adapun tujuan dari pelaksanaan kegiatan pemberdayaan ini adalah sebagai berikut:

a. Dapat membuka wawasan dan memberikan pengetahuan baru bagi ibu-ibu PKK di Saung Singgah TPU Pondok Kopiserta menjadikan mereka pengguna teknologi yang bisa memanfaatkan media internet sebagai sarana pemasaran produk.

b. Diharapkan peserta mampu melakukan praktek berjualan produk melalui media sosial.

c. Diharapkan peserta mampu melakukan praktek berjualan produk melalui marketplace.

Pelatihan menjual produk melalui internet ini diharapkan dapat menambah wawasan bagi ibu-ibu PKK untuk dapat mengetahui wawasan mengenai pemasaran di dunia digital. Selain itu, peserta dapat melakukan kegiatan pemasaran yang efektif dan efisien melalui e-commerce/marketplace dan pemanfaatan media sosial. Kegiatan pelatihan ini dapat dijadikan media bagi peserta untuk dapat berpartisipasi dan terlibat langsung dalam memanfaatkan media komunikasi di era digital.

\section{TINJAUAN PUSTAKA}

\subsection{Pemberdayaan Masyarakat}

Para ilmuwan sosial dalam memberikan pengertian pemberdayaan mempunyai rumusan yang berbeda-beda dalam berbagai konteks dan bidang kajian, artinya belum 
ada definisi yang tegas mengenai konsep tersebut. Namun demikian, bila dilihat secara lebih luas, pemberdayaan sering disamakan dengan perolehan daya, kemampuan dan akses terhadap sumber daya untuk memenuhi kebutuhannya.

Pemberdayaan masyarakat adalah upaya untuk memberikan daya (empowerment) atau penguatan (strengthening) kepada masyarakat. Pemberdayaan masyarakat juga diartikan sebagai kemampuan individu yang bersenyawa dengan masyarakat dalam membangun keberdayaan masyarakat yang bersangkutan sehingga bertujuan untuk menemukan alternatif-alternatif baru dalam pembangunan masyarakat (Mardikanto, 2014). Enam Tujuan pemberdayaan masyarakat, yaitu:

a. Perbaikan kelembagaan (better institution). Dengan perbaikan kegiatan/tindakan yang dilakukan, diharapkan akan memperbaiki kelembagaan, termasuk pengembangan jejaring kemitraanusaha.

b. Perbaikan usaha (better business). Perbaikan pendidikan (semangat belajar), perbaikan aksesibisnislitas, kegiatan dan perbaikan kelembagaan, diharapkan akan memperbaiki bisnis yangdilakukan.

c. Perbaikan pendapatan (better income). Dengan terjadinya perbaikan bisnis yang dilakukan, diharapkan akan dapat memperbaiki pendapatan yang diperolehnya, termasuk pendapatan keluarga danmasyarakatnya.

d. Perbaikan lingkungan (better environment). Perbaikan pendapatan diharapkan dapat memperbaiki lingkungan (fisik dan sosial), karena kerusakan lingkungan seringkali disebabkan oleh kemiskinan atau pendapatan yangterbatas.

e. Perbaikan kehidupan (better living). Tingkat pendapatan dan keadaan lingkungan yang membaik, diharapkan dapat memperbaiki keadaan kehidupan setiap keluarga danmasyarakat.

f. Perbaikan masyarakat (better community). Kehidupan yang lebih baik, yang didukung oleh lingkungan (fisik dan sosial) yang lebih baik, diharapkan akan terwujud kehidupan masyarakat yang lebih baik pula (Mardikanto, 2014, hal. 202).

Suksesnya program pemberdayaan tidak terlepas dari 4 (empat) prinsip yang sering digunakan yaitu prinsip kesetaraan, partisipasi, keswadayaan atau kemandirian, dan berkelanjutan (Najiyati, Asmana, \& Suryadiputra, 2005, hal. 54). Adapun penjelasan terhadap prinsip-prinsip pemberdayaan masyarakat tersebut adalah sebagai berikut: 


\section{a. Prinsip Kesetaraan}

Prinsip utama yang harus dipegang dalam proses pemberdayaan masyarakat adalah adanya kesetaraan atau kesejajaran kedudukan antara masyarakat dengan lembaga yang melakukan program-program pemberdayaan masyarakat, baik lakilaki maupun perempuan.

b. Partisipasi

Program pemberdayaan yang dapat menstimulasi kemandirian masyarakat adalah program yang sifatnya partisipatif, direncanakan, dilaksanakan, diawasi, dan dievaluasi oleh masyarakat..

c. Keswadayaan atau kemandirian

Prinsip keswadayaan adalah menghargai dan mengedepankan kemampuan masyarakat daripada bantuan pihak lain. Konsep ini tidak memandang orang miskin sebagai objek yang tidak berkemampuan (the have not), melainkan sebagai subjek yang memiliki kemampuan sedikit (the have little).

d. Berkelanjutan

Program pemberdayaan perlu dirancang untuk berkelanjutan, sekalipun pada awalnya peran pendamping lebih dominan dibanding masyarakat sendiri. Tapi secara perlahan dan pasti, peran pendamping akan makin berkurang, bahkan akhirnya dihapus, karena masyarakat sudah mampu mengelola kegiatannya sendiri.

\subsection{Pelatihan dan Keterampilan}

Secara umum pelatihan merupakan bagian dari pendidikan yang menggambarkan suatu proses dalam pengembangan organisasi maupun masyarakat. Pendidikan dengan pelatihan merupakan suatu rangkaian yang takdapat dipisahkandalam sistem pengembangan sumberdayamanusia, yang di alamnya terjadi proses perencanaan, penempatan, dan pengembangan tenaga manusia. Dalam proses pengembangannya diupayakan agar sumberdaya manusia dapat diberdayakan secara maksimal, sehingga apa yang menjadi tujuan dalam memenuhi kebutuhan hidup manusia tersebut dapat terpenuhi. Pelatihan adalah suatu bagian pendidikan yang menyangkut proses belajar untuk memperoleh dan meningkatkan keterampilan diluar sistem pendidikan yang berlaku, dalam waktu yang relatif singkat dan dengan metode yang lebih mengutamakan praktek daripada teori (Moekijat, 1993, hal. 3). 
Dalam pengembangan masyarakat, pelatihan diberikan sebagai upaya untuk meningkatkan kemampuan dari warga masyarakat dalam menghadapi tuntutan maupun perubahan lingkungan sekitarnya. Pemberian pelatihan bagi masyarakat bertujuan untuk memberdayakan, sehingga warga masyarakat menjadi berdaya dan dapat berpartisipasi aktif ada proses perubahan. Pelatihan dapat membantu orang atau masyarakat untuk menerapkan ilmu pengetahuan dan kemampuan yang telah dimiliki. Dengan pelatihan juga dapat menimbulkan perubahan dalam kebiasaan-kebiasaan bekerja masyarakat, perubahan sikap terhadap pekerjaan, serta dalam informasi dan pengetahuan yang mereka terapkan dalam pekerjaannya sehari-hari. Kegiatan pelatihan dapat terjadi apabila seseorang atau masyarakat menyadari perlunya mengembangkan potensi dan kemampuan dalam memenuhi kebutuhan maupun kepuasan hidupnya, oleh sebab itu diperlukan kegiatan pemberdayaan.Kegiatan pemberdayaan ini dilakukan dengan cara memberikan pelatihan dasar dalam mempromosikan produk yang dimiliki dengan memanfaatkan kecanggihan teknologi di era digitalisasi.

Pelatihan secara intensif tentu akan dapat menghasilkan sesuatu yang bermanfaat dan bernilai bagi diri sendiri dan orang lain. Pelatihan tersebut juga harus memiliki kualitas yang tinggi karena tanpa pelatihan atau pendidikan yang berbobot dan berkualitas yang dimiliki oleh masyarakat, maka upaya dalam meningkatkan produktivitas seutuhnya sulit untuk diwujudkan. Kualitas ketrampilan sangat menentukan dalam penyiapan sumber daya manusia yang handal. Kualitas ketrampilan dapat dicapai dengan menciptakan iklim pembelajaran yang menyenangkan,sehingga mampu memotivasi dan mendorong semangat serta mampu memberdayakan kemampuan seoptimal mungkin

\subsection{Digital Marketing}

Digital marketing memungkinkan pembeli memperoleh seluruh informasi mengenai produk dan bertransaksi melalui internet, dan memungkinkan penjual memantau dan menyediakan kebutuhan serta keinginan calon pembeli tanpa batasan waktu dan geografis. Digital Marketing adalah pemasaran yang memiliki lingkup lebih luas karena mengacu pada media digital seperti web, e-mail dan media nirkabel, tetapi juga meliputi pengelolaan data pelanggan digital, dan juga bagaimana Internet dapat digunakan bersama dengan media tradisional untuk memperoleh dan memberikan layanan kepada pelanggan (Chaffey, Chadwick, Johnston, \& Mayer, 2009). Digital 
marketing merupakan kegiatan marketing termasuk branding yang menggunakan berbagai media berbasis web seperti blog, website, email, adwords, ataupun jejaring sosial.

Media sosial merupakan aplikasi online, sarana dan media yang ditujukan untuk menfasilitasi interaksi, kolaborasi dan sharing materi (Kotler, Philip T., Keller, Kevin Lane, 2016). Definisi lain media sosial adalah sekelompok aplikasi berbasis internet yang dibangun atas dasar ideologis dan teknologi web 2.0, yang memungkinkan terjadi penciptaan dan pertukaran yang dihasilkan dari pengguna konten (Andreas \& Michael, 2010).

Penelitian pada ibu-ibu PKK sangat merasakan begitu besar manfaat yang diperoleh dengan menggunakan sosial media sebagai sarana kegiatan pemasaran hasil industri rumahannya. hal ini mengindikasikan bahwa digital marketing sangat potensial untuk dikembangkan (Pradiani, 2017) yang sejalan dengan pernyataan berdasarkan alasan atau motivasi pemasar menggunakan media sosial (antecedants) dan target dari progam pemasaran (consequences) yang dapat diraih dengan menggunakan media sosial. Pelanggan akan mendapatkan stimulus dari promosi yang dilakukan pemasar, keluarga, teman, atau komunitas online, untuk menjadi aktif shopping. Stimulus tersebut dapat datang terus menerus di dalam media sosial. Implikasi pemasar terhadap evolusi tersebut adalah brand harus dapat menyebar dan fleksibel, brand harus membangun komunikasi dengan pelanggan dan calon pelanggan (Pratama, 2015).

\section{METODE}

\subsection{Jenis Metode}

Metode yang kami gunakan dalam pelatihan penjualan online ini adalah dengan teknik ceramah dan pelatihan langsung. Adapun ceramah yang kami lakukan adalah memberikan materi pelatihan terkait penjualan online dengan rincian sebagai berikut:

a. Pada hari pertama kami memberikan materi pengetahuan dasar internet marketing.

b. Pada hari kedua kami memberikan materi pelatihan penjualan online melalui mediasosial.

c. Pada hari kedua kami memberikan materi pelatihan penjualan online melalui marketplace. 
Teknik pelatihan langsung dilakukan dengan cara memberikan panduan kepada para peserta untuk mempraktekkan secara langsung bagaimana membuat akun pada media sosial Instagram maupun marketplace. Selain itu para peserta juga diajarkan bagaimana mengunakannya dan membuat pesan persuasif atas produk yang akan dipasarkan.

\subsection{Sasaran Khayalak Program}

Sasaran dalam pelatihan penjualan online ini adalah ibu-ibu PKK yang bertempat tinggal di sekitar Saung Singgah Taman Pemakaman Umum Pondok Kopi, Jakarta Timur dengan berbagai latar belakang.Dari segi pendidikan, sifatnya bebas, baik yang masih berprofesi sebagai ibu rumah tangga yang belum memiliki usaha sendiri ataupun ibu rumah tangga yang sudah memiliki usaha sendiri. Peserta pelatihan merupakan peserta binaan yang telah mengikuti kegiatan ini pada pengabdian masyarakat periode lalu.

\subsection{Tempat dan Waktu}

Kegiatan ini dilaksanakan di Saung Singgah Taman Pemakaman Umum Pondok Kopi secara terjadwal yaitu satu kali dalam seminggu setiap hari Senin pukul 13.00-14.00 WIB selama bulan Desember 2019.

\subsection{Evaluasi Kegiatan (Pre Test dan Post Test)}

Evaluasi kegiatan pengabdian ini dilakukan dengan metode survei, yaitu melalui penyebaran kuesioner. Pengisian kuesioner dilakukan para peserta pelatihan sebanyak 2 kali, pertama sebelum para peserta mengikuti kegiatan pelatihan penjualan online dan yang kedua setelah para peserta selesai mengikuti kegiatan pelatihan tersebut. Kuesioner ini ditujukan kepada 25 (dua puluh lima) peserta pelatihan penjualan online.

\subsection{Roadmap Kegiatan Pengabdian Masyarakat}

Kegiatan pengabdian masyarakat ini memiliki tujuan akhir yaitu para peseta dalam kegiatan pengabdian ini dapat memahami dan menjalankan usaha/bisnis berbasis online. Dalam rangka mencapai tujuan tersebut, maka kegiatan ini memiliki roadmap pengabdian masyarakat yang dibagi menjadi 3 tahapan. Kegiatan pengabdian pada tahun sebelumnya (2018-2019) dilakukan untuk memberikan teknik dasar keterampilan dalam membuat produk yang memiliki nilai ekonomis untuk dijual. Pada kegiatan pengabdian 
tahun 2020-2021 ditunjukkan untuk memberikan pengetahuan dan pemahaman kepada para peserta kegiatan atas penjulan berbasis online, dimana para peserta diajakam untuk menggunakan media sosial Instagram serta marketplace sebagai sarana penjualannya. Pada tahap akhir (2022-2023), para peserta kegiatan dibekali pelatihan usaha kecil berbasis web. Perencanaan kegiatan pengabdian masyarakat ini dituangkan ke dalam suatu model Roadmap. Model itu sendiri dikonstruk dan dibatasi melalui pengukuran dalam struktur, isi, bentuk serta memiliki makna (Husain, 2019), kemudian dituangkan pada suatu roadmap yang pada tahap ini para peserta diajarkan untuk memiliki usaha kecil dengan menggunakan web marketing sebagai sarana dalam memasarkan produk.

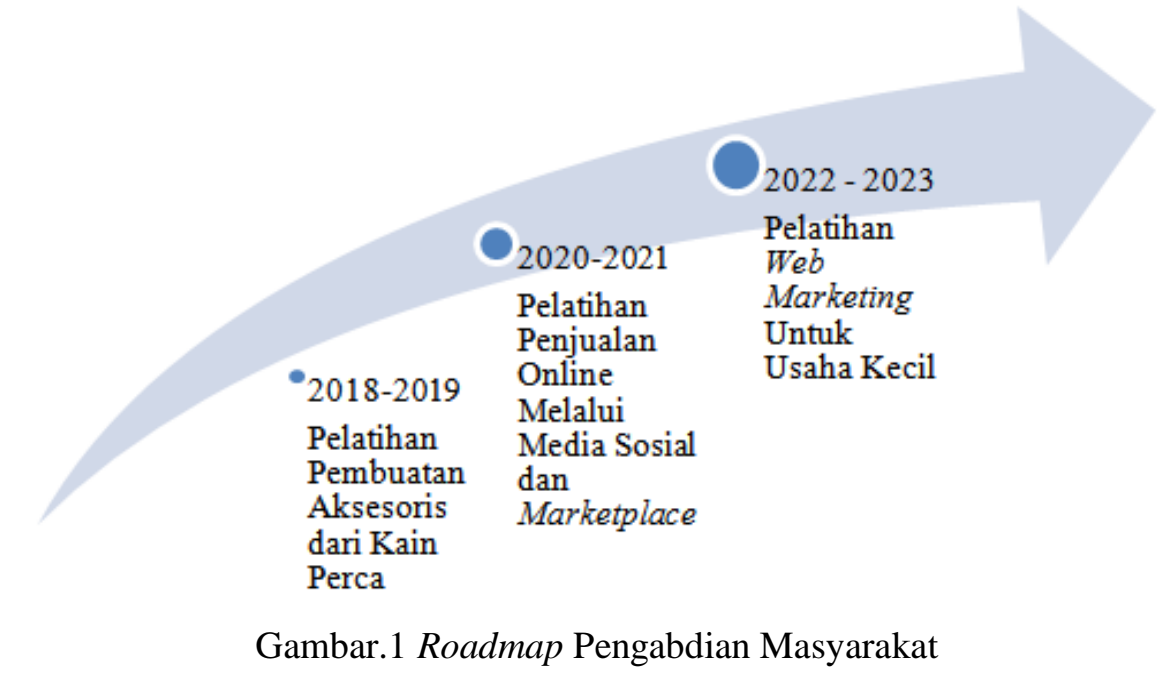

\subsection{Target Luaran}

Target luaran harus terukur dan merupakan parameter keberhasilan program. Adapun luaran yang diharapkan antara lain :
a. Publikasi di jurnal nasional-ISSN/prosiding
b. Produk pengabdian berupa akun media social dan marketplace
c. Kemampuan merancang pesanagresif

\section{HASIL DAN PEMBAHASAN}

\subsection{Hasil Kuesioner Pra Pelatihan (Pre-Test)}

Dari 25 orang peserta yang mengikuti kegiatan pelatihan ini, diketahui terdapat $50 \%$ peserta yang belum pernah sama sekali mengikuti pelatihan penjualan online 
sedangkan ada $14 \%$ yang pernah mengikutinya sekali serta $36 \%$ sisanya pernah mengikuti lebih dari 1 kali.

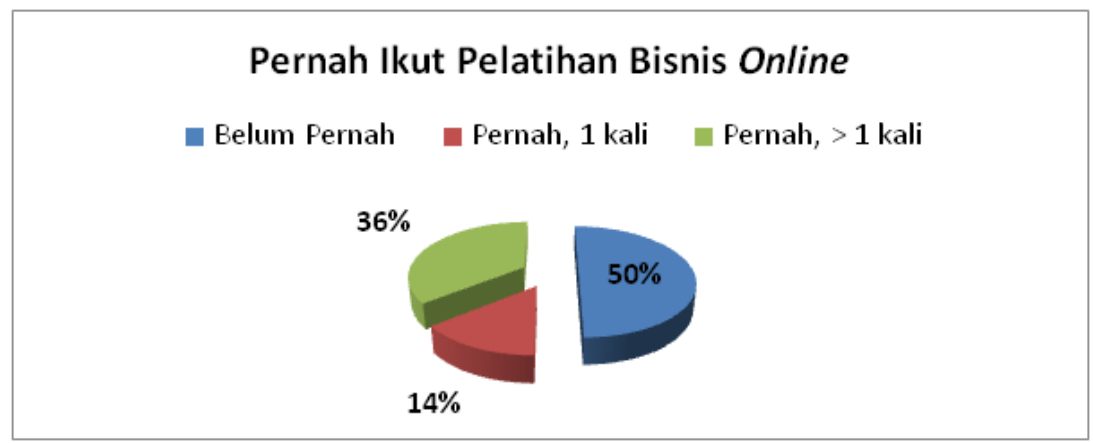

Gambar.2 Pernah Mengikuti Pelatihan Bisnis Online

(Sumber: Hasil Kuesioner, 2020)

Diketahui pula dari 25 peserta pelatihan, terdapat $29 \%$ peserta yang mengetahui dan memahami apa itu bisnisonline, $50 \%$ peserta yang sedikit memahami tentang bisnis online dan ada $21 \%$ peserta yang sama sekali tidak mengerti apa itu bisnis online.

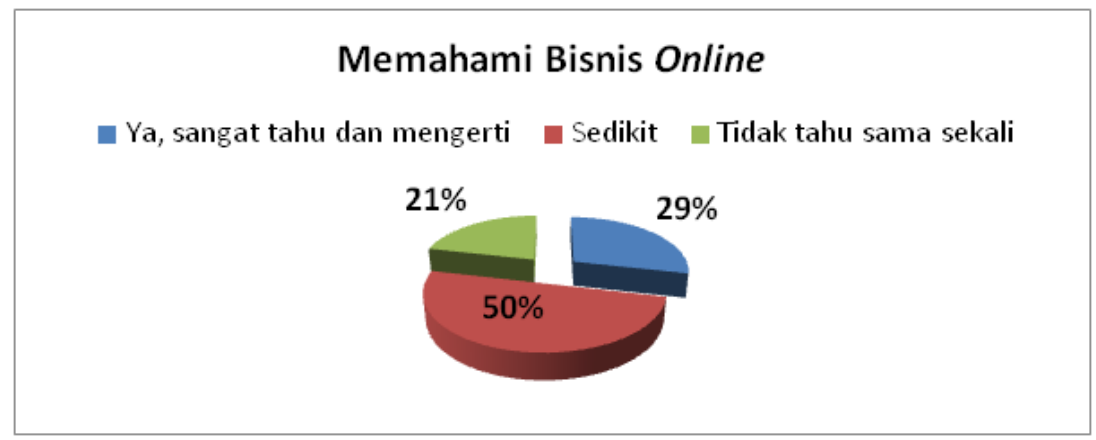

Gambar.3 Memahami Bisnis Online

(Sumber: Hasil Kuesioner, 2020)

Para peserta pelatihan ini, ada yang sudah memiliki bisnis/usaha rumahan sebanyak $29 \%$ dan sisanya $71 \%$ dari peserta pelatihan diketahui tidak memiliki bisnis/usaha sama sekali.

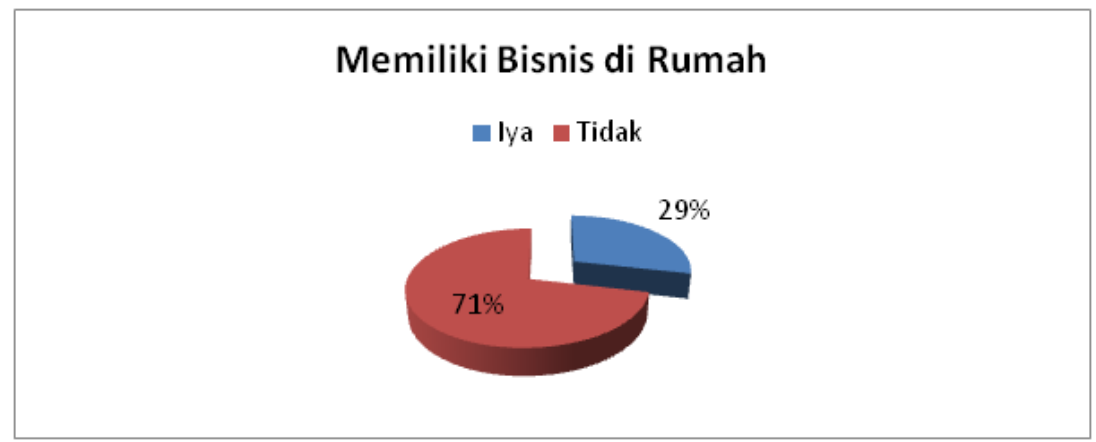

Gambar.4 Memiliki Bisnis di Rumah 
(Sumber: Hasil Kuesioner, 2020)

Diketahui dari tabel dibawah ini terdapat $93 \%$ peserta yang tertarik untuk memiliki bisnis sedikit memahami tentang bisnis online dan ada $7 \%$ peserta yang tidak tertarik memiliki bisnis.

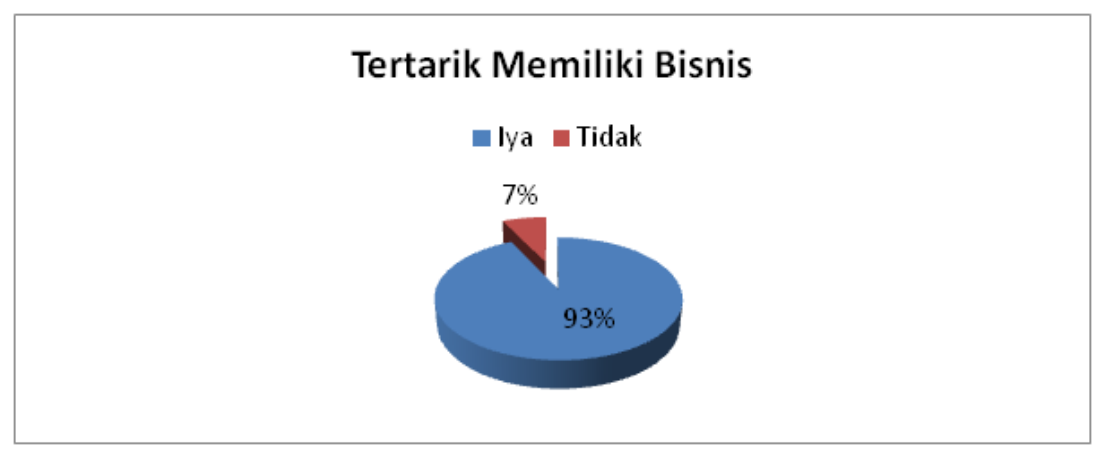

Gambar.5 Tertarik Memiliki Bisnis

(Sumber: Hasil Kuesioner, 2020)

Dari hasil pra kuesioner diketahui bahwa terdapat $7 \%$ peserta yang mengetahui dan mengerti apa itu media sosial Instagram, $79 \%$ peserta yang sedikit memahami tentang media sosial Instagram dan ada $14 \%$ peserta yang sama sekali tidak mengerti apa itu media sosial Instagram.

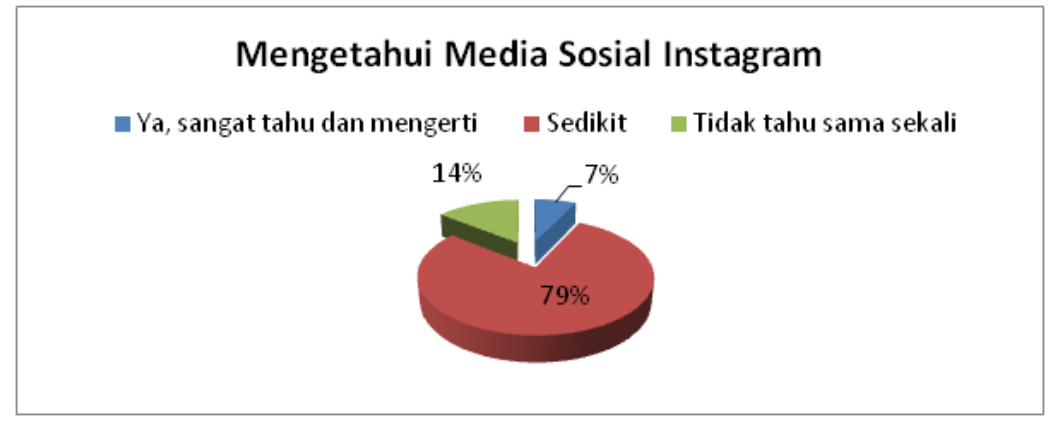

Gambar.6 Mengetahui Media Sosial Instagram

(Sumber: Hasil Kuesioner, 2020)

\subsection{Hasil Kuesioner Pasca Pelatihan (Post-Test)}

Setelah para peserta mengikuti kegiatan pelatihan penjualan online, para peserta diminta untuk mengisi kuesioner kembali untuk mengetahui sejauh mana para peserta bisa memahami materi yang telah disampaikan. Berikut ini adalah hasilnya: 


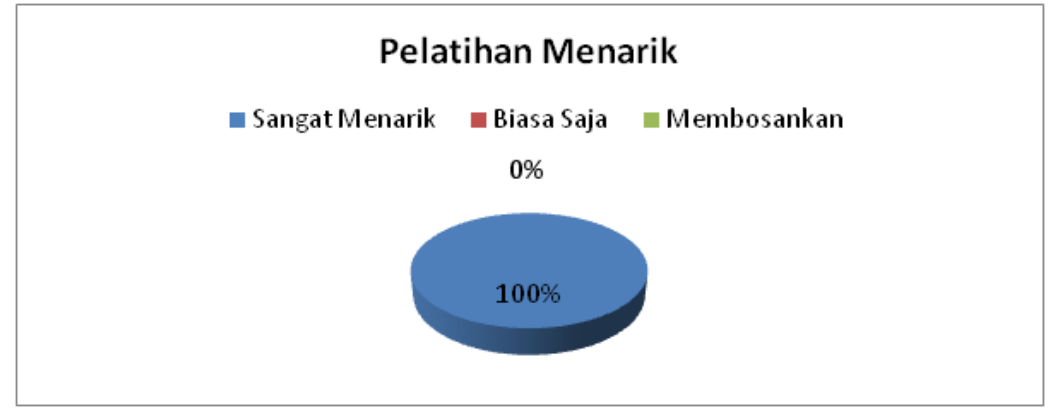

Gambar.7 Pelatihan Menarik

(Sumber: Hasil Kuesioner, 2020)

Selain menarik, para peserta juga menilai bahwa kegiatan pelatihan yang dilakukan sangat bermanfaat bagi mereka. Hal ini dikarenakan mereka mendapatkan wawasan serta pengetahuan akan penjualan online, penggunaan media sosial internet dan marketplace.

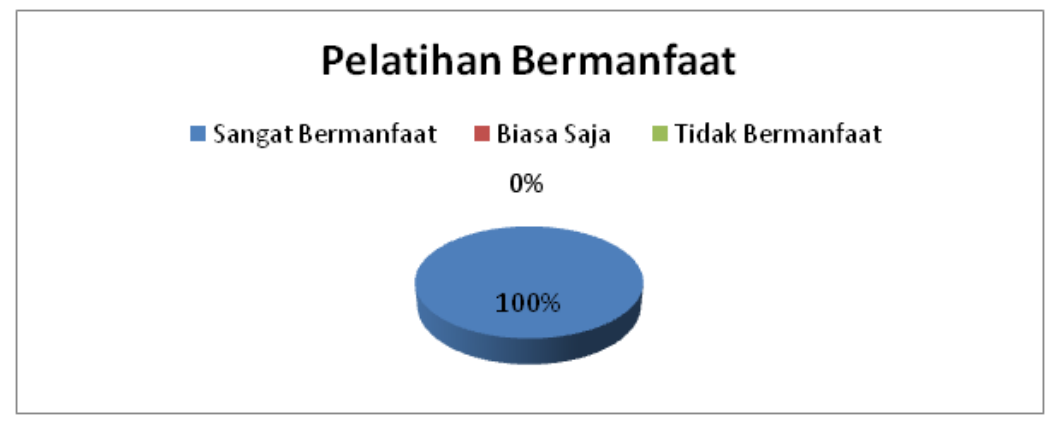

Gambar.8 Pelatihan Bermanfaat

(Sumber: Hasil Kuesioner, 2020)

Jika dibandingkan hasil kuesioner pra pelatihan dengan hasil kuesioner pasca pelatihan, maka diketahui terdapat kenaikan jumlah akan peserta yang memahami akan bisnis online. Dari pengisian kuesioner pasca pelatihan dapat diketahui hanya 7\% peserta pelatihan yang tidak memahami apa itu bisnis online, dan sisanya 93\% peserta pelatihan mengatakan memahami tentang bisnis online.

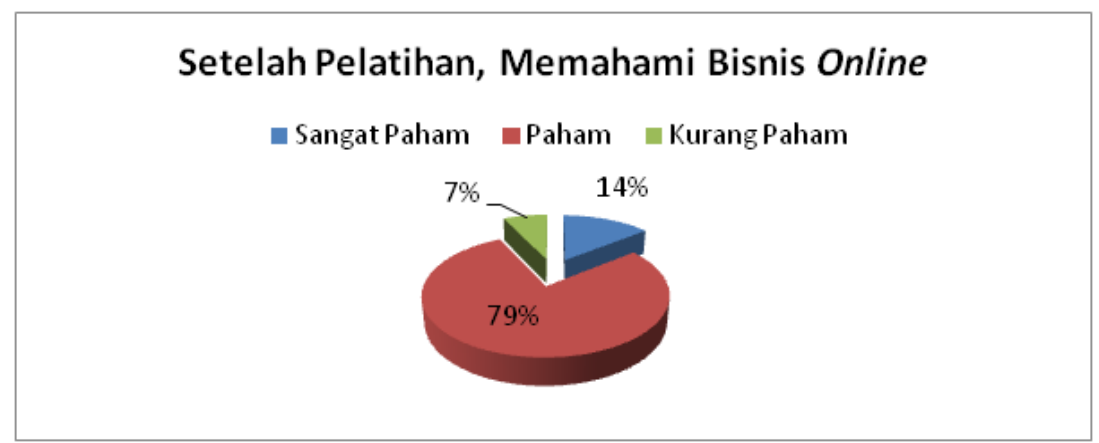


(Sumber: Hasil Kuesioner, 2020)

Jika dibandingkan hasil kuesioner pra pelatihan dengan hasil kuesioner pasca pelatihan, maka diketahui terdapat kenaikan jumlah akan peserta yang tertarik untuk memiliki bisnis online. Dari pengisian kuesioner pasca pelatihan dapat diketahui bahwa seluruh peserta kegiatan tertarik untuk memiliki bisnis online.

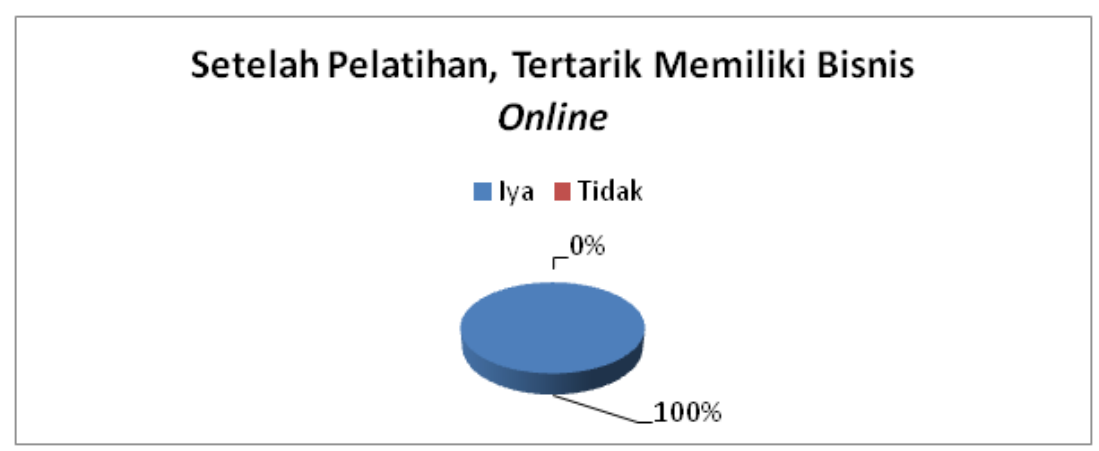

Gambar.10 Setelah Pelatihan, Tertarik Memiliki Bisnis Online

(Sumber: Hasil Kuesioner, 2020)

Hasil akhir kuesioner menunjukkan bahwa ibu-ibu PKK di Saung Singgah TPU Pondok kopi yang menjadi peserta dalam kegiatan ini mengatakan bahwa mereka sangat memerlukan pelatihan lebih lanjut dan mendalam akan penjualan berbasis online. Sehingga dapat disimpulkan bahwa kegiatan pelatihan penjualan online ini perlu dilakukan lagi dalam rangka memberikan pengetahuan mendalam kepada para peserta tersebut.

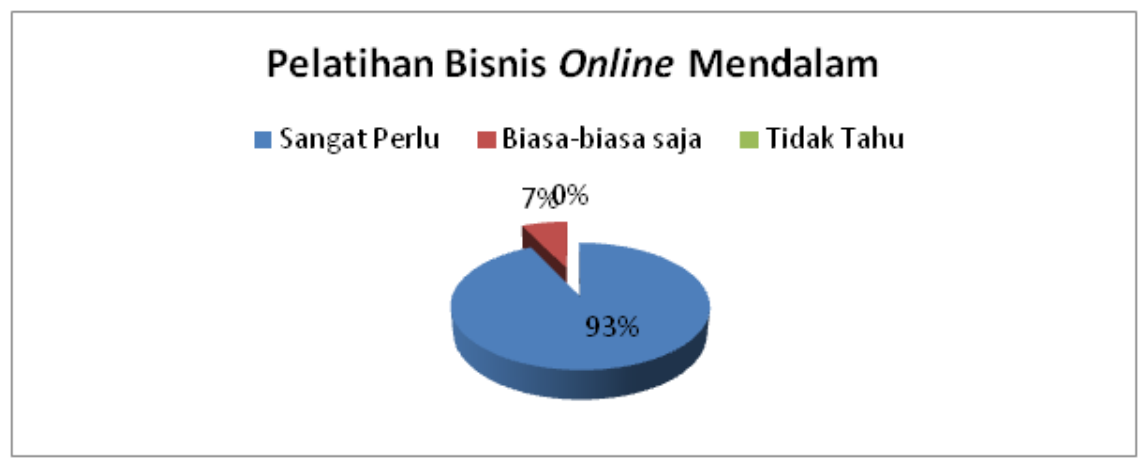

Gambar.11 Pelatihan Bisnis Online Mendalam

(Sumber: Hasil Kuesioner, 2020)

\subsection{Hasil Kegiatan Pengabdian Kepada Masyarakat}


Hasil atas pelatihan ini adalah ibu-ibu rumah tangga di Saung Singgah TPU Pondok Kopimendapatkan wawasan dan pengetahuan baru dalam membuat bisnis berbasis online dengan memanfaatkan media sosial dan marketplace sebagai sarana pemasaran produk. Dari hasil evaluasi yang dilakukan melalui penyebaran kuesioner diketahui $\pm 90 \%$ ibu-ibu PKK tersebut memahami tentang bisnis online, penggunaan media sosial Instagram maupun cara menggunakan marketplace serta pembuatan pesan persuasif dalam rangkan mendorong minat pembelian. Adapun faktor pendorong bagi kegiatan pelatihan ini adalah mayoritas ibu-ibu rumah tangga, baik yang memiliki usaha rumahan (berpenghasilan) ataupun tidak memiliki usaha (tidak memiliki penghasilan), yang belum memgetahui maupun memahami penggunaan internet sebagai media bisnis online. Sehingga perlu diadakannya pelatihan penjualan online ini sebagai modal dalam mencari tambahan untuk keperluan sehari-hari. Faktor penghambat dalam pelaksanaan kegiatan ini adalah terdapat para peserta yang kurang tanggap dalam menangkap materi yang diberikan serta kesulitan saat melakukan praktek langsung atau pembuatan akun dan penggunaan media online (Instagram dan marketplace).

\subsection{Capaian dalam Roadmap}

Kegiatan pengabdian masyarakat ini memiliki tujuan yaitu para peseta kegiatan dapat mengetahui dan memahami bisnis online dengan sarana media sosial Instagram dan marketplace, serta dapat membuat pesan persuasif pada media tersebut guna menciptakan minat pembelian. Capaian ini terdapat pada tahap kedua $(2020$ - 2021) dalam roadmap pengabdian masyarakat, yaitu melakukan pelatihan penjualan online melalui media sosial dan marketplace.

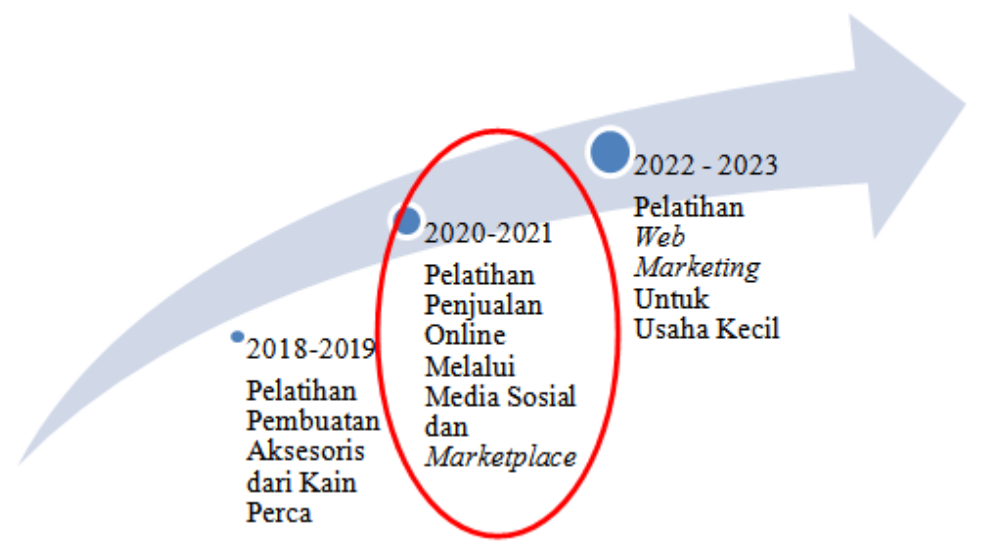

Gambar.12 Capaian Roadmap Pengabdian Masyarakat 


\section{SIMPULAN DAN SARAN \\ 1. Simpulan}

Hasil pelaksanaan kegiatan ini dapat dikatakan cukup baik. Ibu-ibu Rumah Tangga di Saung Singgah TPU Pondok Kopi yang menjadi peserta dalam kegiatan pelatihan ini sudah dapat memahami tentang bisnis online dengan baik, dapat membuat akun pada media sosial Instagram dan marketplace sebagai sarana penjualan onlinedengan cukup baik meskipun untuk pembuatan pesan persuasif masih terdapat ibuibu yang belum bisa dan belum mampu membuat pesan persuasif yang baik.Hasil kuesioner pasca pelatihan menunjukkan bahwa sebagian besar ibu-ibu yang menjadi peserta dalam kegiatan ini mtertarik untuk memiliki bisnis online dan mereka menyatakan memerlukan pelatihan lanjutan yang lebih mendalam terkait binis online. Sehingga kegiatan pelatihan ini kedepannya harus terus dilakukan mengingat tingginya minat dari para peserta kegiatan.

\section{Saran}

Berdasarkan tingginya minat para peserta dalam mengikuti kegiatan pelatihan ini dan adanya kebutuhan pelatihan bisnis online yang lebih mendalam, maka penulis menyarankan agar pelatihan ini dapat dilanjutkan dalam rangka memberikan pengetahuan yang komprehensif akan penggunaan media sosial dan marketplace sebagai sarana penjualan secara online, khususnya bagi ibu-ibu rumah tangga yang memiliki kewajiban untuk mengurus rumah dan minim modal untuk memiliki toko secara fisik.

\section{DAFTAR PUSTAKA}

Andreas, K. M., \& Michael, H. (2010). Users of the world, unite! and opportunities of social media. Business Horizons, 53(1), 61.

Chaffey, D., Chadwick, F. E., Johnston, K., \& Mayer, R. (2009). Internet Marketing: Strategy, Implementation and Practice (4 ed.). Jakarta: Prentice Hall/Financial Times.

Hidayah, D. U., Utami, D. A., Yunita, I. R., Tarwoto, \& Yulistia, T. (2019). Pelatihan Penjualan Online untuk Masyarakat Desa Karanglewas Kidul Kabupaten Banyumas. Abdimas Altruis: Jurnal Pengabdian Kepada Masyarakat, 2(1), 31-37.

Husain, T. (2019). An Analysis of Modeling Audit Quality Measurement Based on Decision Support Systems (DSS). European Journal of Scientific Exploration, 2(6), 1-9. 
Kotler, Philip T., Keller, Kevin Lane. (2016). Marketing Management (15 ed.). New Jersey: Pearson Prentice Hall Inc.

Mardikanto, T. (2014). CSR (Corporate Social Responsibility)(Tanggungjawab Sosial Korporasi). Bandung: Alfabeta.

Moekijat. (1993). Evaluasi Pelatihan DalamRangka Peningkatan Produktivitas. Bandung: Mandar Majau.

Nainggolan, J. (2018). Dua tahun terakhir pengguna internet di indonesia meningkat. Retrieved Juli 21, 2018, from http://ekbis.rmol.co/ read/2018/02/21/327520/Dua-TahunTerakhir-Pengguna-Internet-Di-Indonesia-Meningkat-

Najiyati, S., Asmana, A., \& Suryadiputra, I. N. (2005). Pemberdayaan Masyarakat di Lahan Gambut. Bogor: Wetlands International.

Pradiani, T. (2017). Pengaruh Sistem Pemasaran Digital Marketing terhadap Peningkatan Volume Penjualan Hasil Industri Rumahan. JIBEKA, 11(2), 46-53.

Pratama, I. P. (2015). E-Commerce, E-Business, Dan Mobile Commerce Berbasiskan Open Source Teori Dan Praktek. Bandung: Informatika.

Ramadhan, B. (2018, Februari). Inilah perkembangan digital indonesia tahun 2018. Retrieved Juli 21, 2018, from IPTEK: https://www.goodnewsfromindonesia.id/2018/02/06/inilah-perkembangan-digitalindonesia-tahun-2018 